\title{
The Research on the Ammonium Concentrations in City Stocks and Further Sedimentation of lon-Exchange Concentrate
}

\author{
Myroslav Malovanyy ${ }^{1}$, Halyna Sakalova ${ }^{2 *}$, Tamara Vasylinych ${ }^{2}$, Rostyslav Kryklyvyi \\ 1 Viacheslav Chornovil Institute of Sustainable Development, Lviv Polytechnic National University, Bandera str., \\ 12, Lviv, 79013, Ukraine \\ 2 Vinnytsia Mykhailo Kotsiubynskyi State Pedagogical University, Ostrozhskogo street 32, Vinnitsa, 21100, \\ Ukraine \\ * Corresponding author's e-mail: sakalovag@gmail.com
}

\begin{abstract}
In this work, the exchange capacity and the selectivity of different ion-exchange products regarding the ammonium ions in treatment processes were measured; the regenerative preparation compounds influence on efficiency of conduction of ion-exchange products regeneration was determined. The adsorption processes were adapted to the known technological schemes of sewage and polluted surface water treatment that was polluted with ammonium ions. There were measured the technological aspects of water treatment by using adsorption on natural dispersed sorbents. The technological schemes of drain water treatment from ammonium ions were developed. The method of simultaneous removal of highly concentrated nitrogen and phosphorus was analyzed by physical and chemical precipitation, forming struvite, a by-product of magnesium ammonium orthophosphate hexahydrate. The analyses were conducted at various molar ratios of magnesium and phosphate ions and at various $\mathrm{pH}$ values. The comparative thermal analysis of chemical precipitation products and pure struvite was performed. The optimal conditions were identified to experience the maximum efficiency of simultaneous removal of ammonium nitrogen and phosphate ions from wastewater, forming $\mathrm{MgNH}_{4} \mathrm{PO}_{4} \cdot 6 \mathrm{H}_{2} \mathrm{O}$.
\end{abstract}

Keywords: environmental security, natural clay sorbents, adsorption, ion exchange, ammonium orthophosphate hexahydrate (struvite), thermal analysis

\section{INTRODUCTION}

Anthropogenic eutrophication and water pollution are the main processes that cause degradation of rivers, water reservoirs, lake systems and deterioration of the water quality. The main cause of both processes is the waste of economic activity entering the reservoir from the catchment area. Contamination of reservoirs with toxic substances of anthropogenic origin often complicates or makes it impossible to use water for drinking purposes.

The removal of ammonium nitrogen from water appears to be the most common problem. Usually, ammonium nitrogen can be found in water at $\mathrm{pH}$ level of 6-8. It infiltrates into the surface water with sewage; as a result of ammonification; decomposition of microorganisms of nitrogen- containing organic components (proteins, urea, nucleic acids, etc.), as well as fertilization into the soil. The presence of ammonium ions in water together with nitrates indicates recent water pollution with domestic sewage.

Assessment of surface water objects influenced by the contaminating components of effluents (Kulikova et al., 2016, as well as the analysis of natural of purification systems of effluents filtering from accumulation pounds in the "aeration nature zone-wastewater" system (Pavlichenko et al., 2013) proved to be important. Treatment of the water from various types of pollution by methods such as chlorination (Styskal et al., 2014), ozonization (Mosin, 2011), ultraviolet irradiation (Vronska et al., 2013), ion exchange (Malovanyy et al., 2013), electrodialysis (Gomelia et al., 2017, Shmandiy et al., 2017), biological purification 
(Malovanyy et al., 2016, Malovanyy et al., 2018), adsorption on natural mineral sorbents (Sabadash et al., 2017, Malovanyy et al., 2013) and of plant origin (Danchenko et al., 2017, Bezdeneznych et al., 2009), typically requires expensive reagents and equipment, sometimes also introducing secondary hazardous contaminants to the system (chlorination and ozonation).

These methods are ineffective and difficult to apply. The wastewater from these industries is treated from biogenic elements by conventional biological methods (in aerotanks), while nitrogen compounds are virtually eliminated in them.

The development of new highly-efficient technological schemes for water treatment at the existing wastewater treatment facilities, as well as improvement of the existing wastewater treatment schemes, is one of the ways to solve the problem of discharging insufficiently treated wastewater into water bodies. The application of nitride-denitrification technology in conjunction with dephosphatization requires the improvement of reagent sewage treatment through a detailed study of the formation of weakly soluble magnesium ammonium orthophosphate $\mathrm{MgNH}_{4} \mathrm{PO}_{4} \cdot 6 \mathrm{H}_{2} \mathrm{O}$, which is a valuable fertilizer (Cahil et al., 2008) Implementing this technology under practical conditions, could significantly reduce the need for raw phosphate materials as well as phosphate fertilizer technologies.

The purpose of this study is to develop recommendations on the optimum conditions for the deposition of ammoniacal nitrogen from ion exchange regenerator for its further use as ammonium fertilizer, based on experimental data.

\section{MATERIALS AND METHODS}

The results of previous studies (Malovanyy et al. 2013) showed the possibility of concentration of ammonium ions from wastewater by means of ion exchange. In these studies, ion-exchange materials KU-2-8 or natural zeolite of the Sokirnitsky deposit (Zakarpattia) were saturated with ammonium ions from drain models in the fractioning column until a breakthrough was reached, after which the ion-exchange material was regenerated by pumping $30 \mathrm{~g} / \mathrm{l} \mathrm{NaCl}$ through it. The initial model solution contained $40 \mathrm{mg} / \mathrm{dm}^{3}$ $\mathrm{NH}_{4}^{+}-\mathrm{N}$ (prepared with $\mathrm{NH}_{4} \mathrm{Cl}$ ), $\mathrm{pH}=6$ with a total content of $2.46 \mathrm{mg} / \mathrm{dm}^{3}$ cations. The results of saturation of cation exchanger KU-2-8 and natural zeolite with model solution and subsequent regeneration are presented in Table 1. The maximum saturation of ion-exchange material was determined by increasing the electrical conductivity of the solution at the exit from the column.

As a result of these experiments, we received the ion exchange concentrates, the characteristics of which are given in Table 2.

The research was held at room temperature using the chemical deposition method. Magnesium chloride $\left(\mathrm{MgCl}_{2} \cdot 6 \mathrm{H}_{2} \mathrm{O}\right)$ solution with $\mathrm{Mg}^{2+}$ - $10000 \mathrm{mg} / \mathrm{l}$ concentration and sodium hydrogen phosphate $\left(\mathrm{Na}_{2} \mathrm{HPO}_{4}\right)$ with $\mathrm{PO}_{4}^{3-}-9500 \mathrm{mg} / \mathrm{l}$ concentration were used as precipitators. In order to estimate the optimal conditions for ammonium nitrogen deposition, the experiments with different stoichiometric ratios $\mathrm{Mg}^{2+}: \mathrm{NH}_{4}^{+}: \mathrm{PO}_{4}^{3-}(1: 1: 1$; $1,5: 1: 1 ; 1: 1: 1,5 ; 1,5: 1: 1,5 ; 1: 1,5: 1)$ were conducted. The $\mathrm{pH}$ of the reaction mass was adjusted to various values $(7-11)$ using $10 \% \mathrm{NaOH}$. The $\mathrm{pH}$ of the reaction mass was determined using the method with $\mathrm{pH}$ meter HachSensIon 2 with electrode 51935-00. Substrate agents were added to the model solution in the required volumes to achieve the desired ratio $\mathrm{Mg}^{2+}: \mathrm{NH}_{4}^{+}: \mathrm{PO}_{4}^{3-}$. Afterwards, we adjusted $\mathrm{pH}$ to the specified value. The reaction mass was stirred at $350 \mathrm{rpm} 1 \mathrm{~min}$ (rapid mixing, reaction time), then at $20 \mathrm{rpm}$ for $30 \mathrm{~min}-$ utes (slow stirring, formation of the flocculus). The resulting suspension was protected for 1 hour. The suspension was then filtered, and the resulting filtrate was analyzed for the residual ammonium ions and phosphate ions content. The analy-

Table 1. The results of ion-exchange material saturation with ammonium and its further regeneration

\begin{tabular}{|l|c|c|}
\hline \multicolumn{1}{|c|}{ Index } & Cation exchanger usage $\mathrm{KY}-2-8$ & Natural zeolite usage \\
\hline Volume usage of model solution, $10^{-3} \mathrm{OK} / \mathrm{c}$ & 11.4 & 9 \\
\hline Firsttraces $\mathrm{NH}_{4}{ }^{+}$in cleared water, $\mathrm{OK}$ & 92 & 70 \\
\hline Dynamic exchange capacity, $\mathrm{mg} \mathrm{NH}_{4}^{+}-\mathrm{N} / \mathrm{r}$ & 10.1 & 4 \\
\hline Volume flow of solution for regeneration, $10^{-3} \mathrm{OK} / \mathrm{c}$ & 1.9 & 2 \\
\hline Solution volume for regeneration, $\mathrm{OK}$ & 13 & 120 \\
\hline Regeneration level, $\%$ & 98 & 90 \\
\hline
\end{tabular}


Table 2. Ion exchange concentrates

\begin{tabular}{|l|c|c|}
\hline Ion-exchangematerial & Cationexchanger & Zeolite \\
\hline $\mathrm{NH}_{4}{ }^{+} \mathrm{N}, \mathrm{mg} / \mathrm{l}$ & 550 & 470 \\
\hline $\mathrm{Ca}^{2+}, \mathrm{mg} / \mathrm{l}$ & 280 & 260 \\
\hline $\mathrm{Mg}^{2+}, \mathrm{mg} / \mathrm{l}$ & 240 & 240 \\
\hline $\mathrm{pH}$ & 7 & 6.5 \\
\hline
\end{tabular}

sis was held at photoelectric colorimeter with a method of photometric determination of ammonium ions using the Nessler's reagent in wastewater (KND 211.1.4.030-95, 2006) and method of photometric determination of phosphate ions in wastewater (KND 211.1.4.030-95, 2006).

The obtained data was compared to the initial concentrations in the model solution of the corresponding ions to determine the deposition efficiency.

\section{RESULTS AND DISCUSSION}

Due to the large number of variables in the experiments, it was decided to conduct studies in four groups $(\mathrm{A}, \mathrm{B}, \mathrm{C}, \mathrm{D})$ depending on the molar ratio of ions $\mathrm{Mg}^{2+}, \mathrm{NH}_{4}^{+}, \mathrm{PO}_{4}^{3--}$ : Group A - stoichiometric ratio $\mathrm{Mg}^{2+}: \mathrm{NH}_{4}^{+}: \mathrm{PO}_{4}^{3-}=1: 1: 1$, pH 7; $; ; 9 ; 10 ; 11$. Group B - stoichiometric ratio $\mathrm{Mg}^{2+}: \mathrm{NH}_{4}^{+}: \mathrm{PO}_{4}^{3-}=1.5: 1: 1, \mathrm{pH} \mathrm{7;8;9}$; 10; 11. Group $\mathrm{C}-$ stoichiometric ratio $\mathrm{Mg}^{2+}$ : $\mathrm{NH}_{4}^{+}: \mathrm{PO}_{4}{ }^{3-}=1: 1: 1.5, \mathrm{pH} 7 ; 8 ; 9 ; 10 ; 11$. Group $\mathrm{D}$ - stoichiometric ratio $\mathrm{Mg}^{2+}: \mathrm{NH}_{4}^{+}: \mathrm{PO}_{4}^{3-}=$ 1.5:1:1.5, $\mathrm{pH} 7 ; 8 ; 9 ; 10 ; 11$.

Adjustment of the corresponding stoichiometric ratios $\mathrm{Mg}^{2+}: \mathrm{NH}_{4}^{+}$: $\mathrm{PO}_{4}^{3-}$ was carried out by mixing different volumes of working solutions according to the calculations. Sodium hydrogen phosphate was used as a precipitating agent $\left(\mathrm{Na}_{2} \mathrm{HPO}_{4}\right)$,

The filtrate was analyzed for the content of residual phosphate ions. Therefore, while analyzing the results of the research, attention was drawn not only to the maximum degree of extraction of $\mathrm{NH}_{4}^{+}-\mathrm{N}$, but the degree of extraction of $\mathrm{PO}_{4}^{3-}$.

The main results of precipitation are described in tables 3 and 4 .

It was found that the optimal conditions for the process of reagent precipitation of ammonium nitrogen at the initial concentration $\mathrm{NH}_{4}^{+}-\mathrm{N}$ $-550 \mathrm{mg} / \mathrm{l}$ is the stoichiometric ratio $\mathrm{Mg}^{2+}: \mathrm{NH}_{4}^{+}$:

Table 3. The results of the samples analysis of $\mathrm{NH}_{4}^{+}$and $\mathrm{PO}_{4}^{3-}$ content in solutions (while obtaining an ion exchange concentrate using cation exchanger KУ 2-8)

\begin{tabular}{|c|c|c|c|c|c|}
\hline No. & $\mathrm{pH}$ & $\mathrm{Cm}\left(\mathrm{NH}_{4}^{+}\right), \mathrm{mg}$ & $\mathrm{C}\left(\mathrm{NH}_{4}{ }^{+}-\mathrm{N}\right), \mathrm{mg} / \mathrm{l}$ & $\mathrm{Cm}\left(\mathrm{P}_{2} \mathrm{O}_{5}\right), \mathrm{mg}$ & $\mathrm{C}\left(\mathrm{PO}_{4}{ }^{3-}\right), \mathrm{mg} / \mathrm{l}$ \\
\hline \multicolumn{6}{|c|}{ Group A solutions } \\
\hline 1 & 7 & 3.9644 & 396.4 & 1.0506 & 157.04 \\
\hline 2 & 8 & 0.9310 & 93.1 & 0.5223 & 77.47 \\
\hline 3 & 9 & 0.4129 & 41.3 & 0.3237 & 48.39 \\
\hline 4 & 10 & 0.6271 & 62.7 & 0.3766 & 56.29 \\
\hline 5 & 11 & 2.2778 & 227.8 & 0.8484 & 126.82 \\
\hline \multicolumn{6}{|c|}{ Group B solutions } \\
\hline 1 & 7 & 3.7324 & 373.2 & 1.0306 & 154.05 \\
\hline 2 & 8 & 0.3860 & 38.6 & 0.5314 & 79.43 \\
\hline 3 & 9 & 0.3646 & 36.5 & 0.3401 & 50.85 \\
\hline 4 & 10 & 0.4109 & 41.1 & 0.3036 & 45.39 \\
\hline 5 & 11 & 2.3311 & 233.1 & 0.5751 & 85.97 \\
\hline \multicolumn{6}{|c|}{ Group C solutions } \\
\hline 1 & 7 & 2.0224 & 202.2 & 1.5607 & 233.30 \\
\hline 2 & 8 & 0.7964 & 79.6 & 0.7063 & 105.57 \\
\hline 3 & 9 & 0.4153 & 41.5 & 0.6225 & 93.05 \\
\hline 4 & 10 & 1.7435 & 174.3 & 0.6917 & 103.35 \\
\hline 5 & 11 & 1.8344 & 183.4 & 1.3968 & 208.79 \\
\hline \multicolumn{6}{|c|}{ Group D solutions } \\
\hline 1 & 7 & 3.0511 & 305.1 & 1.6026 & 239.56 \\
\hline 2 & 8 & 0.6907 & 69.1 & 0.7773 & 116.20 \\
\hline 3 & 9 & 0.3683 & 36.8 & 0.5228 & 78.15 \\
\hline 4 & 10 & 0.3801 & 38.1 & 0.9559 & 142.89 \\
\hline 5 & 11 & 1.8933 & 189.3 & 1.5881 & 237.38 \\
\hline
\end{tabular}


Table 4. The results of the samples analysis for $\mathrm{NH}_{4}^{+}$and $\mathrm{PO}_{4}^{3-}$ content in solutions (at obtaining an ion exchange concentrate using zeolite)

\begin{tabular}{|c|c|c|c|c|c|}
\hline No. & $\mathrm{pH}$ & $\mathrm{Cm}\left(\mathrm{NH}_{4}^{+}\right), \mathrm{mg}$ & $\mathrm{C}\left(\mathrm{NH}_{4}{ }^{+}-\mathrm{N}\right), \mathrm{mg} / \mathrm{l}$ & $\mathrm{Cm}\left(\mathrm{P}_{2} \mathrm{O}_{5}\right), \mathrm{mg}$ & $\mathrm{C}\left(\mathrm{PO}_{4}{ }^{3-}\right), \mathrm{mg} / \mathrm{l}$ \\
\hline \multicolumn{6}{|c|}{ Group A solutions } \\
\hline 1 & 7 & 58.6526 & 456.19 & 2.7162 & 157.04 \\
\hline 2 & 8 & 29.1789 & 226.95 & 1.2147 & 77.47 \\
\hline 3 & 9 & 24.9684 & 194.20 & 0.9144 & 48.39 \\
\hline 4 & 10 & 20.7579 & 161.45 & 1.9655 & 56.29 \\
\hline 5 & 11 & 21.8105 & 169.64 & 2.1156 & 126.82 \\
\hline \multicolumn{6}{|c|}{ Group B solutions } \\
\hline 1 & 7 & 54.4421 & 423.44 & 1.2147 & 301.25 \\
\hline 2 & 8 & 27.0737 & 210.57 & 1.0646 & 264.01 \\
\hline 3 & 9 & 15.4947 & 120.51 & 0.9144 & 226.77 \\
\hline 4 & 10 & 13.3895 & 104.14 & 2.2658 & 561.91 \\
\hline 5 & 11 & 37.6000 & 292.44 & 3.0165 & 748.10 \\
\hline \multicolumn{6}{|c|}{ Group C solutions } \\
\hline 1 & 7 & 53.3895 & 415.25 & 3.0165 & 748.10 \\
\hline 2 & 8 & 23.9158 & 186.01 & 2.2658 & 561.91 \\
\hline 3 & 9 & 14.4421 & 112.33 & 1.5150 & 375.72 \\
\hline 4 & 10 & 18.6526 & 145.08 & 1.0646 & 264.01 \\
\hline 5 & 11 & 20.7579 & 161.45 & 0.7643 & 189.54 \\
\hline \multicolumn{6}{|c|}{ Group D solutions } \\
\hline 1 & 7 & 41.8105 & 325.19 & 1.3649 & 338.49 \\
\hline 2 & 8 & 30.2316 & 235.13 & 1.2147 & 301.25 \\
\hline 3 & 9 & 2.8632 & 22.27 & 0.9144 & 226.77 \\
\hline 4 & 10 & 3.9158 & 30.46 & 0.4640 & 115.06 \\
\hline 5 & 11 & 10.2316 & 79.58 & 0.7643 & 189.54 \\
\hline \multicolumn{6}{|c|}{ Group E solutions } \\
\hline 1 & 7 & 77.6000 & 603.56 & 0.7643 & 189.54 \\
\hline 2 & 8 & 71.2842 & 554.43 & 0.6141 & 152.30 \\
\hline 3 & 9 & 43.9158 & 341.57 & 0.6141 & 152.30 \\
\hline 4 & 10 & 40.7579 & 317.01 & 0.9144 & 226.77 \\
\hline 5 & 1 & 43.9158 & 341.57 & 1.5150 & 375.72 \\
\hline
\end{tabular}

$\mathrm{PO}_{4}{ }^{3-}=1,5: 1: 1$ (option $\mathrm{B}$ ). The results of the best option of lab research group were aggregated in a combined diagram, which shows the effectiveness of precipitation of $\mathrm{NH}_{4}^{+}-\mathrm{N}$ depending on the $\mathrm{pH}$ (Figure 1).

This way, it was estimated that the maximum effectiveness of ammonia nitrogen removal is reached at a $\mathrm{pH}$ of about 9 and at a ratio $\mathrm{Mg}^{2+}$ : $\mathrm{NH}_{4}^{++}: \mathrm{PO}_{4}^{3-}=1.5: 1: 1.5$. A change of ratio $\mathrm{Mg}^{2+}$. $: \mathrm{NH}_{4}^{+}: \mathrm{PO}_{4}^{3-}$ at $9 \mathrm{pH}$ level leads to reducing effectiveness $\mathrm{NH}_{4}^{+}-\mathrm{N}$. A further growth of $\mathrm{pH}$ leads to a sharp decrease in the efficiency of removal of ammonium ions.

The results from group D, as the best lab sample, are reflected in a combined diagram, which shows the effectiveness of $\mathrm{NH}_{4}^{+}-\mathrm{N}$ precipitation which depends on $\mathrm{pH}$ at $\mathrm{Mg}^{2+}: \mathrm{NH}_{4}^{+}: \mathrm{PO}_{4}^{3-}=$ $1.5: 1: 1.5$ ratio (Figure 2 ).

It was established that the maximum efficiency of ammonium nitrogen removal at its initial concentration in the regenerate $470 \mathrm{mg} / \mathrm{l}$ is achieved at approx. $8.5 \mathrm{pH}$ level with $\mathrm{Mg}^{2+}: \mathrm{NH}_{4}^{+}$: $\mathrm{PO}_{4}{ }^{3-}=1.5: 1: 1.5$ ratio. The change of correlation $\mathrm{Mg}^{2+}: \mathrm{NH}_{4}^{+}: \mathrm{PO}_{4}^{3}$ at $8.5 \mathrm{pH}$ leads to a reduction of the $\mathrm{NH}_{4}{ }^{+}-\mathrm{N}$ removal efficiency. A further $\mathrm{pH}$ growth results in a high decrease of the $\mathrm{NH}_{4}^{+}-\mathrm{N}$ removal efficiency. At a maximum level of ammonium nitrogen removal efficiency, the level of $\mathrm{PO}_{4}^{3-}$ removal is maximum too, at $8.5 \mathrm{pH}$ level and $\mathrm{Mg}^{2+}: \mathrm{NH}_{4}^{+}: \mathrm{PO}_{4}{ }^{3-}=1.5: 1: 1.5$ ratio.

On the basis of the results pertaining to the best options, deposition of real concentrates of ion exchange was carried out. The degree of $\mathrm{NH}_{4}^{+}$$\mathrm{N}$ ions deposition for concentrate excluded from cationite was $94.5 \%$, and for the concentrate extracted from zeolite $-93.91 \%$, which means that the results almost do not differ from the values of samples concentrates in which the proportion of adsorbed ions is $\mathrm{NH}_{4}^{+}-\mathrm{N}-93.91 \%$.

The weight method was used to determine the moisture level of the precipitate. At the starting level $550 \mathrm{mg} / \mathrm{l}$ of $\mathrm{NH}_{4}^{+}-\mathrm{N}$ concentration, 


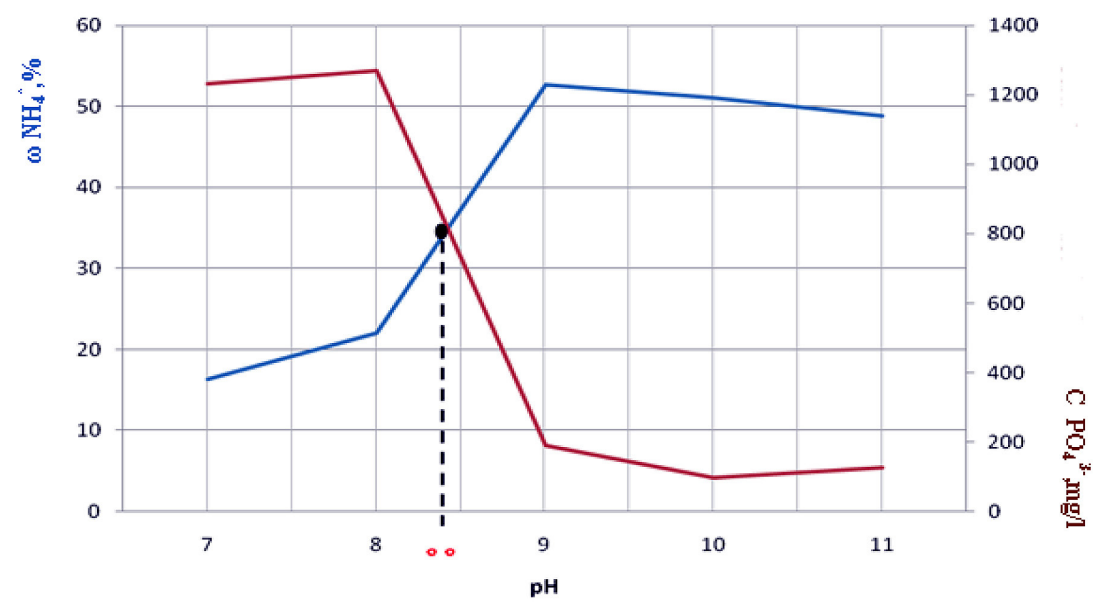

Figure 1. Optimal conditions of simultaneous removal of ammonium nitrogen and phosphate ions in solution B

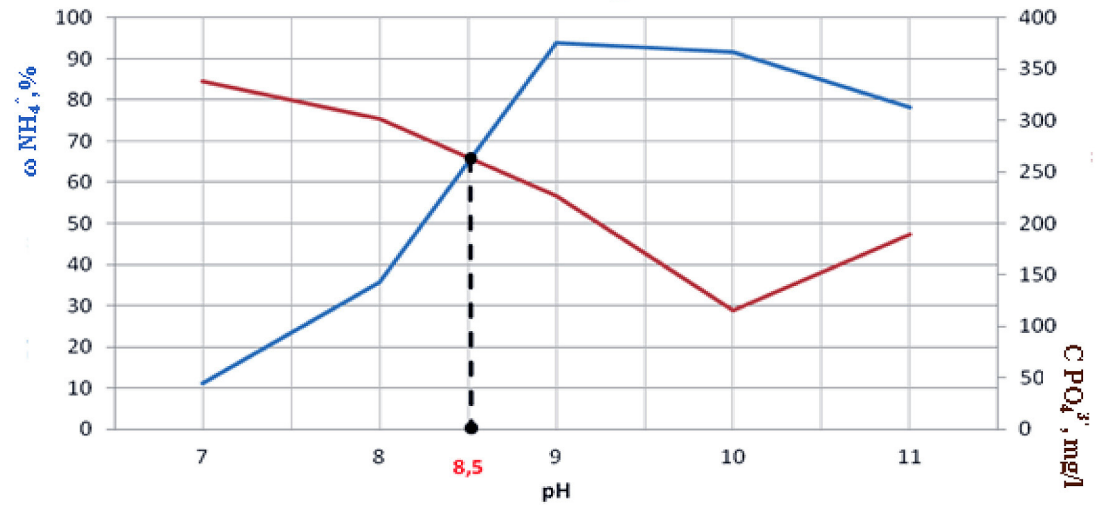

Figure 2. Optimal conditions for a simultaneous removal of ammonium nitrogen and phosphate ions in solution

obtained under the chosen optimal conditions $\left(\mathrm{Mg}^{2+o f}: \mathrm{NH}_{4}^{+}: \mathrm{PO}_{4}^{3-}=1.5: 1: 1, \mathrm{pH} 9\right)$ it amounted to $33.07 \%$ moisture, but at the level $470 \mathrm{mg} / 1$ of $\mathrm{NH}_{4}^{+}-\mathrm{N}$ concentration and optimal conditions $\mathrm{Mg}^{2+}: \mathrm{NH}_{4}^{+}: \mathrm{PO}_{4}^{3-}=1.5: 1: 1.5, \mathrm{pH} 8.5$, the moisture level was $40.7 \%$. The calculation of the moisture content of the precipitate enabled to establish a crystal hydrate formula: in the first case, it is $\mathrm{MgNH}_{4} \mathrm{PO}_{4} \times 4.5 \mathrm{H}_{2} \mathrm{O}$, in the other $\mathrm{MgNH}_{4} \mathrm{PO}_{4} \times 4 \mathrm{H}_{2} \mathrm{O}$.

The precipitate formed as a result of the physicochemical precipitation of ammonium and phosphorus ions was analyzed with a thermogravimetric method.

The differences in the chemical composition of the samples were determined by examining their thermal stability compared to the chemically pure crystalline matrix MgNH4PO4 $6 \mathrm{H}_{2} \mathrm{O}$, a sample of SIGMA-ALDRICH, with a content of $99.997 \%$ of the basic substance (Tulaydan et al., 2017).

The thermograms of pure crystalline hydrate sample and a prototype are shown in Figures 3 and 4, respectively. The presented thermograms are a set of curves TG, DTG, DTA. The TG and DTG curves reflect the sample mass loss during heating and the mass loss rate, and the DTA curve depicts the changes in the sample temperature and reference substance temperature difference as well as characterizes the magnitude and type of thermal effect.

Similarity of the TG and DTG curves indicates the similarity of their mechanism of thermal destruction. By the nature of mass loss and total mass loss at the end of the process, the test sample is very similar to the sample of pure crystalline hydrate. The partial discrepancy of the sample mass loss of $\mathrm{MgNH}_{4} \mathrm{PO}_{4} \cdot 4,5 \mathrm{H}_{2} \mathrm{O}$ and $\mathrm{MgNH}_{4} \mathrm{PO}_{4} \cdot 6 \mathrm{H}_{2} \mathrm{O}$ at different stages of thermolysis, indicates a possible presence of a small amount of impurities in the sample in the form of magnesium hydroxide and calcium hydrophosphates. On the other hand, the difference in the amount of water characterizes the differences in the passage of the first stage. The presence of impurities is caused by the conditions of physical and chemical deposition analysis. 


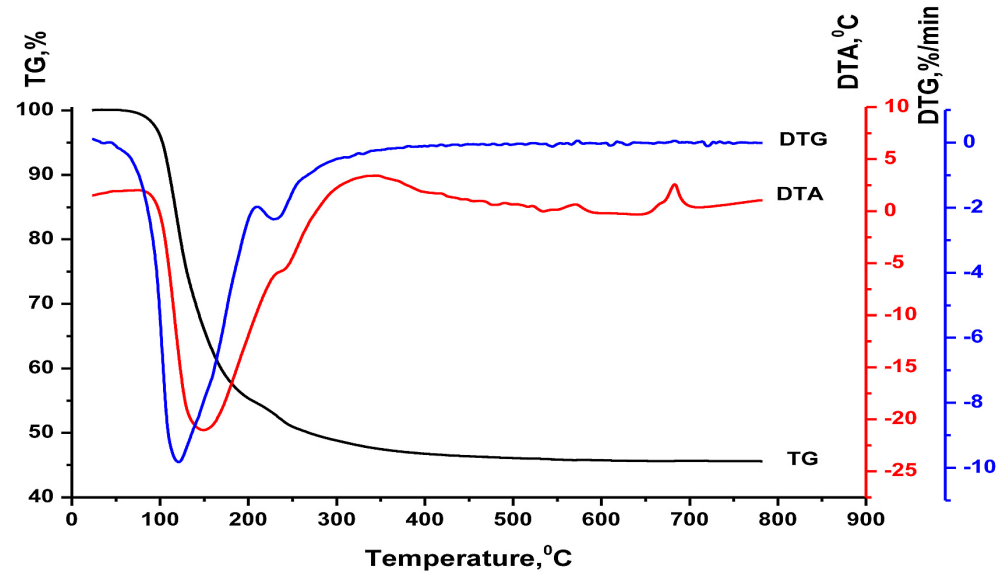

Figure 3. The thermogram of pure crystalline hydrate $-\mathrm{MgNH}_{4} \mathrm{PO}_{4} \cdot 6 \mathrm{H}_{2} \mathrm{O}$

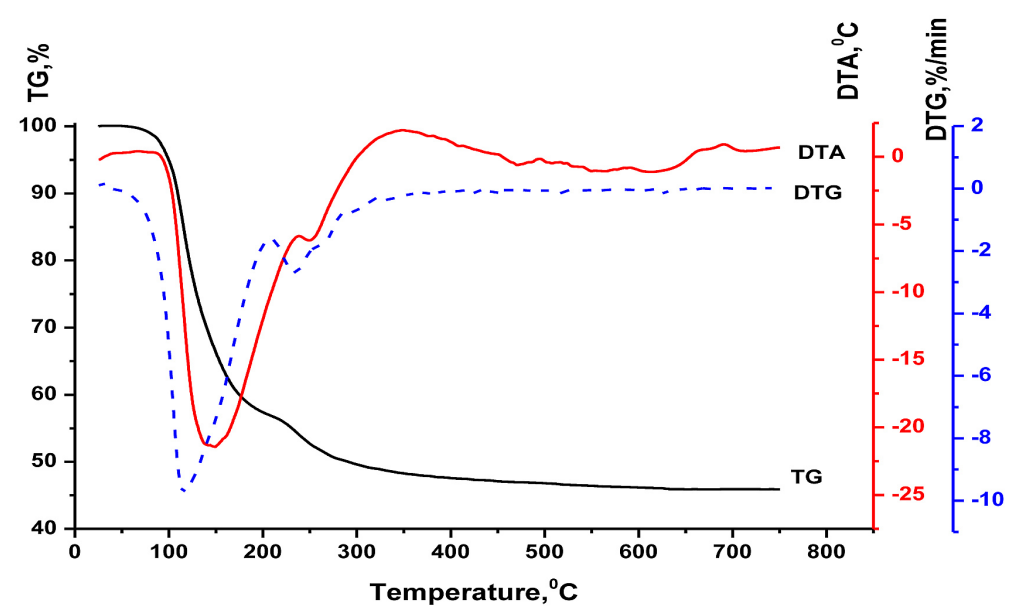

Figure 4. The thermogram of received crystalline hydrate $-\mathrm{MgNH}_{4} \mathrm{PO}_{4} \cdot 4.5 \mathrm{H}_{2} \mathrm{O}$

The behavior of the resulting precipitate at thermal heating allows us to conclude that this product can be used as a fertilizer on the industrial level. During drying and granulation, the fertilizer does not lose nutrients. During the heating of fertilizers to more than $200^{\circ} \mathrm{C}$, they can lose part of the crystallization - bound water, as well as a part of nutrient nitrogen in the form of ammonia.

\section{CONCLUSIONS}

1. A series of experimental studies were carried out on sample solutions. We obtained the following results:

2. The reagent method allows simultaneous removal of ammonia and phosphates with the achievement of the proportion of adsorbed ions up to $95 \%$ and up to $98 \%$, respectively.
3. The most optimal conditions for the process of reagent precipitation of ammonia nitrogen at the initial concentration of $\mathrm{NH}_{4}^{+}-\mathrm{N}-550 \mathrm{mg} / 1$ is $\mathrm{pH} 9$ and the stoichiometric ratio is $\mathrm{Mg}^{2+}$ : $\mathrm{NH}_{4}^{+}: \mathrm{PO}_{4}^{3-}=1.5: 1: 1.5$. In this case, the proportion of adsorbed ions is $\mathrm{NH}_{4}^{+}-\mathrm{N}-52.69 \%$, $\mathrm{PO}_{4}^{3-}-96.6 \%$. At the initial concentration of $\mathrm{NH}_{4}^{+}-\mathrm{N}-470 \mathrm{mg} / \mathrm{l}$, the optimum conditions for the process of reagent precipitation of ammonia nitrogen are $\mathrm{pH} 8.5$ and the stoichiometric ratio is $\mathrm{Mg}^{2+}: \mathrm{NH}_{4}^{+}: \mathrm{PO}_{4}^{3-}=1.5: 1: 1.5$.

4. The moisture level was set during the drying of the mineral fertilizers. On the basis of the moisture values, we determined the content of the precipitate, which is close to the number of water molecules to the formula of fertilizer $\mathrm{MgNH}_{4} \mathrm{PO}_{4} \cdot 5 \mathrm{H}_{2} \mathrm{O}$.

5. The behavior of the resulting precipitate obtained from the ion exchange concentrate, at thermal heating, suggests that the product can 
be used as fertilizer on an industrial scale. Nutrients (nitrogen and phosphorus) would not be lost while drying and granulating fertilizer.

\section{REFERENCES}

1. Bezdeneznych L., Alekseeva T. 2009. Possibility a peelings of sewages from ions of heavy metals. Environmental Safety, 6(2), 54-57.

2. Cahil A., Soptrajanov B., Najdoski M., Lutz H.D., Engelen B., Stefov V. 2008. Infrared and Raman spectra of magnesium ammonium phosphate (struvite) and its isomorphous analogues. Part VI: FT-IR spectra of isomorphously isolated species. NH4+ ions isolated in $\mathrm{MKPO} 46 \mathrm{H} 2 \mathrm{O}(\mathrm{M}=\mathrm{Mg} ; \mathrm{Ni})$ and $\mathrm{PO} 43$ - ions insolated in MgNH4AsO4.6H2O. Journal of Molecular Structure, 876(1-3), 255-259.

3. Danchenko, Y., Andronov, V., Kariev, A., Meleshchenko, R., Yavorska, D. 2017. Research into surface properties of disperse fillers based on plant raw materials. Eastern European Journal of Enterprise Technologies, 12(89), 20-26.

4. Gomelya M.D., Grabitcenko V.M., Radovenchik V.M., Makarenko I.B. 2017. Obtaining chlorine by electrolysis concentrates of reverse osmosis desalination. Proceedings of the NTUU "Igor Sikorsky KPI". Series: Chemical Engineering, Ecology and Resource Saving, 1, 58-65.

5. KND 211.1.4.030-95. 2006. Method of photometric determination of ammonium ions with Nessler's reagent in sewage. Method of photometric determination of phosphate ions in sewage, Ministry of Environmental Protection of Ukraine, 11, p. 20 (in Ukraine)

6. Kulikova D.V., Pavlychenko A.V. 2016. Estimation of ecological state of surface water bodies in coal mining region as based on the complex of hydrochemical indicators. Scientific Bulletin of National Mining University, 4, 62-70.

7. Malovanyy A., Sakalova G., Yatchyshyn Y., Plaza E., Malovanyy M. 2013. Concentration of ammonium from municipal wastewater using oin exghange process. Desalination, 329, 93-102.

8. Malovanyy M., Shandrovych. V., Malovanyy A., Polyuzhyn. I. 2016. Comparative Analysis of the
Effectiveness of Regulation of Aeration Depending on the Quantitative Characteristics of Treated Sewage Water. Journal of Chemistry, $9 \mathrm{p}$.

9. Malovanyy M., Zhuk V., Sliusar V., Sereda A. 2018. Two stage treatment of solid waste leachates in aerated lagoons and at municipal wastewater treatment plants. Eastern-European Journal of Enterprise Technologies, 1(10), 23-30.

10. Mosin O.V. 2011. The use of ozone in water treatment. Plumbing, Heating, Air conditioning, 9(117). 40-43.

11. Pavlichenko, A.V., Kroik, A.A. 2013. Geochemical assessment of the role of aeration zone rocks in pollution of ground waters by heavy metals. Scientific Bulletin of National Mining University, 5, 93-99.

12. Petruk R., Petruk H., Kryklyvyi R., Bezvozyuk I. 2016. Technological aspects of environmentally friendly processes of domestic phosphorites reduction. Chemistry \& Chemical Technology, 10(1), 55-63.

13. Sabadash, V., Mylanyk, O., Matsuska, O., Gumnitsky, J. 2017. Kinetic regularities of copper ions adsorption by natural zeolite. Chemistry \& Chemical Technology, 11(4), $459-462$.

14. Shmandiy V., Bezdeneznych L., Kharlamova O., Svjatenko A., A. Malovanyy A., Petrushka K., Polyuzhyn I. 2017. Methods of salt content stabilization in circulating water supply systems. Chemistry \& Chemical Technology, 11(2), $242-246$.

15. Styskal O., Petruk V. 2014. Analysis of factors of environmental hazards of chlorinated drinking water. Visnyk Vinnytsia Politechnical Institute, 5, 69-75.

16. Tulaydan Yu., Malovanyy M., Kochubei V., Sakalova H. 2017. Treatment of high-strength wastewater from ammonium and phosphate ions with the obtaining of struvite. Chemistry \& Chemical Technology, 11(4), 463-468.

17. Vakal, S., Karpovych, E., Malyovannyi, M., Stokalyuk, O. 2014. Development of ammophos production technology from Algerian phosphorites. Chemistry \& Chemical Technology, 8(1), 89-82.

18. Vronska N., Malovanyy M., Koval I., Starchevskyy V. 2016. Integrated adsorption and ultrasonic technology for water treatment processes. Environmental Problems, 1(1), 65-68. 